\title{
Free trade or just trade? The World Trade Organisation, human rights and development (Part 1)
}

\author{
CEPHAS LUMINA \\ Independent expert of the United Nations Human Rights Council on the effects \\ of foreign debt and related financial obligations of States on the full enjoyment \\ of human rights, particularly economic, social and cultural rights;
}

Senior Lecturer, Faculty of Law, University of KwaZulu-Natal

\section{INTRODUCTION}

The World Trade Organisation (WTO) came into being in 1995. It lies at the centre of the global trading system and is one of the most influential international organisations. Its key purpose is to improve "the standards of living" of the people of its Member States by establishing legally binding rules which help trade to flow as freely as possible. ${ }^{1}$ The WTO seeks to achieve trade liberalisation through a variety of actions, including the removal of trade barriers and ensuring that all the main participants in the global trading system are aware of the applicable rules. The organisation also serves as a forum for trade negotiations amongst its Members concerning their multilateral trade relations in matters dealt with under the various agreements annexed to the WTO Agreement, and for settling trade disputes.

In recent years the WTO has been the focal point of intense criticism concerning the perceived negative impact of its agreements on people's livelihoods worldwide. Common criticisms are that the WTO is not working in the interests of the majority of its Members; global trade, as presently organised, only serves the interests of large multinational corporations; the WTO poses a threat to democracy, environmental justice, labour laws and nations' control of their destinies; and that the global trading system (underpinned by the WTO) does not address the concerns of developing countries but exposes them to pressures from powerful countries. ${ }^{2}$ Significantly, the

1 See the Marrakesh Agreement Establishing the World Trade Organisation ("WTO Agreement") of 15 April 1994, 1867 UNTS 154, Preamble, paras 1 and 2.

2 For example, the Global Exchange states: "By promoting the free trade agenda of multinational corporations above the interests of local communities, working families and the environment, the World Trade Organisation has systematically undermined democracy around the world”. The Global Exchange is an international human rights non-governmental organisation founded in 1988. It seeks to promote global social, economic and environmental justice through raising public awareness of the root causes of injustice and lobbying the US Government and private institutions to support policies that promote sustainable development. See http://www.globalexchange.org/campaigns/wto/ (access confirmed: 19 August 2006). On criticisms concerning the WTO generally, see Clapham Human 
WTO has been criticised for lacking sensitivity towards human rights and for lack of transparency in its processes. ${ }^{3}$ It is asserted, among other things, that provisions of WTO agreements concerning agricultural trade and intellectual property directly affect the ability of governments to fulfil their human rights obligations to their citizens. ${ }^{4}$ Conversely, supporters of the WTO argue that by expanding global trade the organisation in fact assists in raising living standards around the world.

It is notable that developed countries (which mainly advocate free trade) have been calling for a broader international trade agenda encompassing non-trade issues such as environmental standards, labour standards and human rights. ${ }^{5}$ They argue that, as currently formulated, the WTO rules do not permit a country to impose trade sanctions to induce another country to improve its human rights practice. Consequently, the WTO rules should be modified to include human rights concerns. However, developing countries oppose these proposals due to concerns that human rights clauses in trade agreements could be used a tool by developed countries to deny market access to products from developing countries. ${ }^{6}$

The purpose of this article is to assess some of the above-mentioned concerns from a human rights perspective and to explore the relationship between trade, human rights and development. The article is divided into two parts. The first part sets the context for the discussion by presenting an overview of the history and functions of the WTO, a discussion of the linkages between trade liberalisation, human rights and development, and an assessment of the human rights obligations of the WTO, if any. The second part will

Rights Obligations of Non-State Actors (2006) 161-163; Cottier Pauwelyn and Burgi Bonanomi (eds) Human Rights and International Trade (2005); Howse "How to Begin to Think About the 'Democratic Deficit' at the WTO" in Griller (ed) International Economic Governance and Non-Economic Concerns: challenges for the international legal order (2003) 79-102; Dommen "Raising Human Rights Concerns in the World Trade Organization: Actors, Processes and Possible Strategies" (2002) 24 Human Rights Quarterly 1-50; Lim "Trade and Human Rights - What's at Issue?" (2001) 35 Journal of World Trade 275-300; OHCHR "Globalisation and its impact on the full enjoyment of human rights", Report of the High Commissioner for Human Rights submitted in accordance with Commission on Human Rights Resolution 2001/32, UN Doc.E/CN/2002/54, 15 January 2002, paras 2-10; Kothari "Globalisation, Social Action and Human Rights" in Mehra (ed) Human Rights and Economic Globalisation: Directions for the WTO (1999) 37-60.

3 For example, Howse and Mutua lament "the atmosphere of secrecy and the lack of transparency in the dispute settlement and appellate process within the WTO". See Howse and Mutua Protecting Human Rights in a Global Economy: Challenges for the World Trade Organization available at http:// www.dd-rd.ca/english/commdoc/publications/globalization/wtoRightsGlob.html (access confirmed: 21 August 2006).

4 See Oxfam Patents versus Patients: Five Years after the Doha Declaration (2006); Oxfam Rigged Rules and Double Standards: Trade, Globalization, and the Fight Against Poverty (2002); and Oxfam Cut the Cost, Patent Injustice: How World Trade Rules Threaten the Health of Poor People (2001).

5 See, for example, De Wet "Labour Standards in the Globalized Economy: the Inclusion of a Social Clause in the General Agreement on tariffs and Trade/World Trade Organization" (2002) 36 Journal of World Trade 883-901; Srinivasan "Trade and Human Rights" in Deardoff and Stern Constituent Interests and US Trade Policies (1998) 225-253; Communication from the Commission to the Council, the European Parliament and the Economic and Social Committee, Promoting Core Labour Standards and Improving Social Governance in the Context of Globalisation, COM (2001) 416 Final, 18 July 2001 available at http://eur-lex.europa.eu/LexUriServ/LexUriServ. do?uri=Com:2001:0416:FIN:EN:PDF (access confirmed: 21 February 2008).

6 See WTO Understanding the WTO (2003, rev 2007) 74. 
explore the human rights implications of two controversial WTO agreements: the Agreement on Trade-Related Aspects of Intellectual Property (the TRIPS Agreement) and the Agreement on Agriculture, with a specific focus on the right to health and the right to food. The conclusion highlights the key issues in the discussion and suggests that the WTO's trade liberalisation agenda should be more responsive to human rights. The human rights perspective is particularly relevant because the majority of WTO Member States have ratified one or more of the core universal human rights instruments and thereby assumed legally binding obligations to promote and protect human rights. ${ }^{7}$ These obligations remain binding on the Member States at all times, also in the context of their membership of international organisations established primarily to deal with non-human rights issues.

\section{THE WTO: AN HISTORICAL OVERVIEW ${ }^{8}$}

The WTO trading system dates back to the General Agreement on Tariffs and Trade (GATT) of 30 October 1947 which provided the rules for the global trading system from 1948 to 1994 . GATT was intended to be a provisional arrangement pending the establishment of an International Trade Organisation (ITO) as the main international trade institution and a specialised agency of the United Nations. ${ }^{9}$ However, GATT was never ratified and the ITO never came into existence, although it spawned an unofficial ad hoc international trading institution also known as the GATT which serviced GATT, the treaty. ${ }^{10}$ Over the years, GATT evolved through several rounds of trade negotiations, including the Uruguay Round of Multilateral Trade Negotiations ${ }^{11}$ which culminated in the establishment of the WTO. ${ }^{12}$ On 15 April 1994 the Final Act Embodying the Results of the Multilateral Trade Negotiations of the Uruguay Round ${ }^{13}$ was signed at Marrakesh, Morocco, by representatives of most of the 124 governments and the European Communities that had participated in the negotiations. The WTO was established in terms of an agreement attached to the Final Act - the Agreement Establishing the World Trade Organisation (WTO Agreement) - and came into existence on 1 January $1995 .{ }^{14}$

7 For example, of the 151 WTO Members, 127 States are parties to the International Covenant on Civil and Political Rights 1966 (as at 28 January 2008), 125 are parties to the International Covenant on Economic, Social and Cultural Rights 1966 (as at 11 November 2007) and all, except the US, are parties to the Convention on the Rights of the Child 1989 (as at 12 February 2008). See http://www2. ohchr.org/english/bodies/ratification/ (access confirmed: 27 February 2008).

8 For a history of the GATT/WTO, see generally Wouters and De Meester The World Trade Organization: A Legal and Institutional Analysis (2007); WTO (fn 6 above) 15-19; Dommen (fn 2 above) 10-13; Jackson The World Trade Organization: Constitution and Jurisprudence (1998); Thomas and Meyer The New Rules of Global Trade: A Guide to the World Trade Organization (1997).

9 Dommen (fn 2 above) 10-13; Thomas and Meyer (fn 8 above) 2-5.

10 Jackson (fn 8 above) 16-19.

11 From 1986 to 1994.

12 The Round was launched in Punta del Este, Uruguay, in September 1986.

13 Annexed to the WTO Agreement are the agreements on goods, services, and intellectual property, dispute settlement, trade policy review mechanism and plurilateral agreements.

14 It should be noted that the WTO is not a specialised agency of the United Nations. However, its relations with the UN are governed by the Arrangements for Effective Cooperation with other Intergovernmental Organizations - Relations Between the WTO and the United Nations, signed on 15 November 1995. 
The WTO Agreement is an umbrella agreement establishing the WTO structure and many other agreements to which all Member States must generally subscribe. ${ }^{15}$ The original GATT of 1947 (the agreement) has been incorporated into the General Agreement on Tariffs and Trade of 1994 ("GATT 1994"), one of the new WTO Agreements. It is notable, however, that whereas the original GATT focused largely on trade in goods, the WTO and its agreements cover trade in services, intellectual property, dispute settlement and trade policy reviews as well. Further, unlike the WTO, the GATT (the institution) was provisional and did not have the status of an international organisation in law. However, the GATT is now the principal set of rules governing trade in goods. ${ }^{16}$ Altogether there are about 60 WTO agreements and separate commitments (called schedules) made by individual states in specific areas - for example, lower customs duties and opening of service markets.

The WTO agreements are ostensibly designed to allow the multilateral trading system to operate on a non-discriminatory basis. They stipulate Members' rights and obligations, with each Member receiving guarantees that its exports will be treated fairly and consistently in other Members' markets and undertaking to reciprocate in respect of imports into its own markets. ${ }^{17}$ The WTO system also allows developing countries some flexibility in implementing their commitments. ${ }^{18}$

As indicated above, membership of the WTO entails commitment to the GATT/WTO agreements. The WTO agreements, which are negotiated and ratified by most trading nations, are in essence contracts enjoining the parties to keep their trade policies within agreed limits. ${ }^{19}$ There are three main objectives of the WTO agreements: to assist the free flow of trade, to achieve further liberalisation gradually through negotiation, and to set up a neutral means of settling disputes. Thus, the agreements generally aim to assist the smooth conduct of international commerce.

The key functions of the WTO include administering the WTO agreements; assisting developing and transitional economies; providing specialised assistance for export promotion through the International Trade Centre; facilitating

15 Article II:2 of the WTO Agreement provides: "The Agreements and associated legal instruments included in Annexes 1, 2 and 3 (hereinafter referred to as "Multilateral Trade Agreements") are integral parts of this Agreement, binding on all Members". In Brazil-Desiccated Coconut (below) the Appellate Body referred, inter alia, to arts II:2 and II:4 and Annex 1A of the WTO Agreement to illustrate the "single undertaking" nature of the WTO Agreement. It stated that " $[\mathrm{t}]$ he single undertaking is further reflected in the provisions of the WTO Agreement dealing with original membership, accession, non-application of the Multilateral Trade Agreements between particular Members, acceptance of the WTO Agreement, and withdrawal from it. Within this framework, all WTO Members are bound by all the rights and obligations in the WTO Agreement and its Annexes 1, 2 and 3" (BrazilMeasures Affecting Desiccated Coconut, WT/DS22/AB/R, 12 [1997]). See also Argentina-Measures Affecting Imports of Footwear, Textiles, Apparel and Other Items, WT/DS56/AB/R, par 81 (1998). The term "single undertaking" refers to the idea that the results of the Uruguay Round negotiations would form a single package to be implemented as a single treaty.

16 GATT 1994 must be read together with the GATT of 1947. See art 1 of GATT 1994.

17 This is in accordance with the well-known "most-favoured nation" principle. The principle is enshrined in varying formulations in the main WTO agreements. See GATT, art 1; General Agreement on Trade in Services (GATS), art 2; TRIPS Agreement, art 4.

18 WTO (fn 6 above) 11

19 Ibid 8. 
cooperation in global economic policy-making; cooperating with other international organisations (including regional trading organisations); ${ }^{20}$ providing a forum for trade negotiations; settling trade disputes; monitoring the trade policies of Members; and facilitating communication concerning changes to Members' trade policies. ${ }^{21}$

As at 27 July 2007 the WTO had 151 Members (including the European Union) and 30 states with observer status. ${ }^{22}$ A Member has access to the privileges that the other Members give to it and the security that the trading rules offer. However, this is dependent on the Member concerned undertaking to open its markets and abide by the rules. According to the WTO, the organisation is "member-driven" and all decisions are taken by consensus among the Members. ${ }^{23}$

\section{TRADE LIBERALISATION, HUMAN RIGHTS AND DEVELOPMENT}

Trade liberalisation - the reduction of artificial barriers to international trade in goods and services - has been a key aspect of international trade and is one of the most significant characteristics of globalisation in recent years. ${ }^{24}$ It is designed to help achieve "free trade" - an idea pioneered by Adam Smith (1723-1790), David Ricardo (1772-1823) and other classical economists. ${ }^{25}$ Free trade is a market model in which trade of goods and services between countries flows unimpeded by government-imposed tariff and non-tariff barriers. It also encompasses the absence of policies or factors (such as taxes, subsidies or regulations) which tend to distort trade by giving domestic businesses, households or factors of production an advantage over foreign ones. Free trade has been defined as a "general openness to exchange goods and information between and among nations with few-to-no-barriers-to-trade". ${ }^{26}$ The concept is reflected in a proliferation of free trade agreements.

It has been asserted that one of the most "obvious means of encouraging trade" is the lowering of barriers to trade such as customs duties (or tariffs) and measures such as import bans or quotas that restrict quantities selectively. ${ }^{27}$ According to the WTO,

20 Nearly all members of the WTO are party to one or more regional trade agreements. Some 250 regional trade agreements had been notified to the GATT/WTO as of December 2002.

21 WTO (fn 6 above) 109.

22 With the exception of the Holy See (government of the State of the Vatican City), observer states must begin accession negotiations within five years of becoming observers.

23 WTO (fn 6 above) at 101.

24 Nevertheless, there are many barriers to international trade including protection of agricultural markets, bias towards domestic service providers and restrictions on international mobility of most types of labour. See McCulloch N Winters LA and Cirera X Trade Liberalization and Poverty: A Handbook (2002) 5 .

25 For a discussion of the evolution of free trade, see generally, Irwin D Against the Tide: An Intellectual History of Free Trade (1996).

26 Eisenberg J Free Trade versus Fair Trade available at http://www.aworldconnected.org/article. php?id=5608print=1 (access confirmed: 12 July 2006).

27 WTO (fn 6 above) 11. 
"liberal trade policies - policies that allow the unrestricted flow of goods and services sharpen competition, motivate innovation and breed success. They multiply the rewards that result from producing the best products, with the best design, at the best price."28

This argument resonates with economists, many of whom support the view that free trade is a net gain to both parties involved in international trade and that the benefits derived from free trade far outweigh the losses. ${ }^{29}$ They contend that trade liberalisation significantly contributes to poverty alleviation and improving the living standards of people. Trade liberalisation, it is argued, increases average incomes and thereby provides states with more resources with which to address poverty. ${ }^{30}$

Some economists assert that trade liberalisation can impact on poverty in three ways: through its impact on the prices of goods; through its impact on profits and therefore on employment and remuneration; and through its impact on government fiscal policies. ${ }^{31}$ Nevertheless, they caution that the impact of trade liberalisation on poverty is "very country-specific". ${ }^{32}$ Consequently, the policy makers in each country must identify the avenues through which each aspect of trade liberalisation might affect poverty..$^{33}$

Conversely, it is contended that some aspects of the WTO agreements render it difficult for countries to pursue policies that other countries have previously successfully employed to address poverty. One such argument is that the implementation of the TRIPS Agreement hampers governments' efforts to provide cheaper access to essential drugs. ${ }^{34}$

It is important to acknowledge that international trade can make a positive contribution to the realisation of human rights by increasing access to employment, higher income and access to a range of economic and social rights. ${ }^{35}$ Indeed, the United Nations (UN) Committee on Economic, Social and Cultural Rights ("the ESCR Committee") has acknowledged "the advantages of an international trading system" underpinned by the WTO which aims, inter alia, to achieve "higher standards of living, steady growth of real income, full employment and economic growth compatible with sustainable development" and has recognised "the wealth-generating potential of trade liberalisation". Nevertheless, the ESCR Committee has also cautioned that

28 Ibid 13. See also WTO The Future of the WTO. Addressing Institutional Challenges in the New Millenium (2004) 10-14.

29 See Friedman and Friedman "The Case for Free Trade" (1997) 4 Hoover Digest available at http:// www.hoover.org/publications/digest/3550727.html (access confirmed: 30 January 2007). See also Irwin Free Trade under Fire, 2 ed (2005); Wolf Why Globalization Works (2004); Bhagwati In Defense of Globalization (2004).

30 McCulloch et al (fn 24 above); Irwin (fn 25 above) 20-69; Kanji and Barrientos Trade Liberalization, poverty and livelihoods: understanding the linkages (2002) 1. The World Bank defines poverty as comprising three key factors: lack of opportunity, insecurity and vulnerability, and powerlessness. See World Bank Attacking Poverty: World Development Report 2000/2001 (2001).

31 McCulloch et al (fn 24 above) 11 .

32 Ibid.

33 Ibid.

34 To be discussed in Part 2 of this article

35 See Skogly Beyond National Borders: States" Human Rights Obligations in International Cooperation (2006) 190. 
"liberalisation in trade, investment and finance does not necessarily create and lead to a favourable environment for the realisation of economic, social and cultural rights. Trade liberalisation must be understood as a means, not an end. The end which trade liberalisation should serve is the objective of human well-being to which the international human rights instruments give legal expression. In this regard the Committee wishes to remind WTO members of the central and fundamental nature of human rights obligations. At the World Conference on Human Rights held in 1993 in Vienna, 171 States declared that the promotion and protection of human rights is the first responsibility of Governments." 36

Consequently, the ESCR Committee has urged the WTO to undertake a review of international trade and investment policies and rules in order to ensure that these are consistent with human rights. In similar vein, in 1999, the UN Sub-Commission on the Promotion and Protection of Human Rights called for measures to be taken "to ensure that human rights principles and obligations are fully integrated in future negotiations in the World Trade Organisation". ${ }^{37}$ These entreaties by key UN human rights bodies clearly indicate concern about the human rights implications of WTO trade policies and rules.

\subsection{Free trade versus just trade}

Free trade is one of the most contentious subjects in international trade. It is beyond the scope of this article to detail the debate but a sketch of the main issues is instructive. While many economists are in favour of free trade, as indicated above, many anti-globalisation groups oppose it for a variety of reasons. Free trade is also usually opposed by domestic industries that are directly at risk of being hurt by it. Those that oppose free trade - labelled the "fair trade" or "trade justice" movement - seek to promote equitable international labour, environment and social standards for the production of goods and services that are exported from developing countries to developed countries. ${ }^{38}$ Fair trade has been defined as

"a trading partnership, based on dialogue, transparency and respect, that seeks greater equity in international trade. It contributes to sustainable development by offering better trading conditions to, and securing the rights of, marginalised producers and workers especially in the South." ${ }^{39}$

Fair trade focuses on promoting, amongst other things, poverty alleviation and sustainable development, gender equity, safe and healthy working conditions for producers, transparency and accountability in the global trading system, and sound environment practices. ${ }^{40}$ It is thus concerned with exchanges upon terms which meet the demands of justice. ${ }^{41}$

36 Statement of the UN Committee on Economic, Social and Cultural Rights to the Third Ministerial Conference of the World Trade Organisation, Seattle, 30 November to 3 December 1999 (26 November 1999) UN Doc.E/C.12/1999/9, para 6.

37 Resolution 1999/30, 26 August 1999.

38 Fair trade proponents include a diversity of international religious, development aid, social and environmental organisations such as Caritas International, Oxfam, and Amnesty International.

39 Definition offered by FINE, an informal Association of the four main Fair Trade networks (Fairtrade Labelling Organizations International, International Fair Trade Association, Network of European Worldshops and European Fair Trade Association) available at http://en.wikipedia.org/wiki/Fair_ trade (access confirmed: 12 July 2006).

40 International Fair Trade Association Key Principles of Fair Trade available at http://www.ifat.org/ downloads/monitoring/copandstds/stds4ftos.doc (access confirmed: 30 January 2007).

41 Eisenberg (fn 26 above). 
Advocates of "fair" or "just" trade contend that trade between developed countries and developing countries takes place along "coercive" and "uneven lines" and should be made more equitable. ${ }^{42}$ They argue further that trade relations between rich and poor countries are based on the latter's dependency on the former and entail terms of trade which are injurious and unfair to poor countries. ${ }^{43}$ In their estimation, free trade does little to protect poor (peripheral) countries which become increasingly dependent on the wealthy (core) countries. ${ }^{44}$

According to the proponents of fair trade, the current terms of trade between developed and lesser developed countries are unjust because the prevailing market prices for the goods produced in the least developed countries are too low for the labourers to get wages that are compatible with human dignity. ${ }^{45}$ Conversely, fair trade practices help alleviate poverty, enhance gender equity, and improve working conditions, the environment and distributive justice. ${ }^{46}$ Free trade poses a threat to these goals. In the view of Harriet Lamb, Director of the Fairtrade Foundation, "world trade rules are currently topsy-turvy, protecting the rich and leaving the poor vulnerable". ${ }^{47}$

A key concern of fair trade advocates is the lack of free trade caused by dumping practices and protectionism (including agricultural subsidies) by the developed (rich) countries. ${ }^{48}$ Developed countries are criticised for their hypocrisy in using protectionism against poorer countries, particularly in agricultural products, while requiring them to leave their own producers without protection. Large agricultural subsidies in the developed countries impede the ability of agricultural producers in poor countries to exercise much of their comparative advantage in agricultural production. For example, when developing countries export to rich country markets, they face tariff barriers that can be as much as four times higher than those which rich countries are subjected to. Without such protectionism by the wealthier countries, poor countries' prospects of alleviating poverty would be improved. It is interesting to note that even the proponents of free trade acknowledge that most African and other developing and least developed countries would benefit immensely (heavily dependent as they are on agricultural exports) if the developed countries ended "egregious policies like the Common Agricultural Policy". ${ }^{9}$

\footnotetext{
42 See http://www.globalenvision.org/library/15/834/ (access confirmed: 27 February 2008).

43 See Cardoso and Faletto Dependency and Development in Latin America (1979).

44 This is referred to as "the dependency thesis". See Cardoso and Faletto (fn 43 above).

45 Eisenberg (fn 25 above).

46 Ibid.

47 Singleton Trade Justice or Free Trade? (2005) 6.

48 It has been asserted that, in 2000, every cow in the European Union (EU) received the equivalent of US\$913 in subsidy while every person in Sub-Saharan Africa received US \$8 in EU aid and that two-fifths of the entire EU budget is spent on subsidising European farmers to the detriment of farmers in the developing world. See Vander Weyer "Can Free Trade Be Fair?" New Statesman available at http://www.newstatesman.com/200502280013 (access confirmed: 28 February 2008).

49 Singleton (fn 47 above) 13; Pollard Mingardi Philippe and Gabb EU Trade Barriers Kill A Centre for New Europe Report, 4 September 2003 available at http://www.cne.org/pub_pdf_2003_09_04_EUbarriers_kill_pdf (access confirmed: 30 January 2007).
} 
By contrast, free trade proponents argue that free trade is consistent with the demands of justice and, in the long term, benefits all countries - rich or poor - when the markets are allowed to come to equilibrium. Thus, they argue, free trade is fair trade. For example, Brink Lindsey and Milton Friedman have suggested that free trade is fair because it involves voluntary exchanges which, in turn, imply an absence of coercion. ${ }^{50}$

It is noteworthy that the proponents of free trade as well as of fair trade claim that they are concerned with global justice; that is, they are concerned with poverty alleviation and global prosperity. ${ }^{51}$ However, while free trade proponents regard voluntariness as the key component of justice, fair trade advocates consider the expression of human dignity as the core issue in global justice. ${ }^{52}$ Thus, free trade advocates argue that the best way to alleviate poverty is to allow countries to trade freely while advocates of fair trade contend that further trade liberalisation would essentially intensify the existing unevenness of trade.

\subsection{Human rights, trade and development}

It is important to recognise at the outset that human rights are widely considered as the end purpose of development. ${ }^{53}$ Thus, the ESCR Committee has repeatedly emphasised that "the realms of trade, finance and investment are in no way exempt from human rights obligations and principles" and that "international organisations with specific responsibilities in those areas should play a positive and constructive role in relation to human rights". ${ }^{54}$ In this regard it is arguable that the WTO has a responsibility to respect human rights. It is significant that most of the Member States of the WTO are parties to one or more of the major human rights treaties. ${ }^{55}$ As such they are obliged to respect and fulfil the human rights norms that they have voluntarily accepted through ratification of the relevant instruments.

It is also worthy of note that the former UN Secretary-General, Kofi Annan, has suggested that failure to act on human rights and other considerations will undermine the credibility of the global trading system. ${ }^{56}$

50 See Lindsey Against the Dead Hand: The Uncertain Struggle for Global Capitalism (2001); Friedman Capitalism and Freedom 2 ed (1982). See also Norberg In Defense of Global Capitalism (2003).

51 See http://www.globalenvision.org/library/15/834/ (access confirmed: 27 February 2008).

52 Ibid.

53 See UNDP Integrating Human Rights with Sustainable Human Development (1998). The rightsbased definition of development in art 1 of the UN Declaration on the Right to Development of 1986 indicates that development is a comprehensive economic, social, cultural and political process which aims at the constant improvement of the well-being of all human beings.

54 See UN Doc.E/C.12/1999/9 (fn 36 above) par 2. See also "Substantive issues arising in the implementation of the International Covenant on Economic, Social and Cultural Rights: Human rights and intellectual property", Statement by the Committee on Economic, Social and Cultural Rights, 14 December 2001, Doc.E/C.12/2001/15.

55 See fn 7 above.

56 Allmand "Trading in Human Rights: The Need for Human Rights Sensitivity at the World Trade Organisation" A Brief by Warren Allmand (President ICHRDD) to the Standing Committee on Foreign Affairs and International Trade. Montreal, Canada. 24 March (1999) Rights and Democracy available at http://www.ichrdd.ca/english/commdoc/publications/globalization/globalAllmand.html (access confirmed: 30 January 2007). 
There is essentially no conflict between international trade law and international human rights law. Both seek to improve standards of living and the rules of international trade implicitly recognise the significance of human rights. For example, in the Preamble to the WTO Agreement, the Members of the organisation acknowledge "that their relations in the field of trade and economic endeavour should be conducted with a view to raising standards, ensuring full employment and a large and steadily growing volume of real income. ${ }^{57} \mathrm{~A}$ number of provisions of the GATT also have some human rights dimensions. ${ }^{58}$

In its report for the 2003 WTO Ministerial Meeting at Cancun, Mexico, the Office of the High Commissioner for Human Rights (OHCHR) identified several linkages between trade and human rights. ${ }^{59}$ These include trade and non-discrimination (focusing on gender equality), TRIPS and public health (focussing on "neglected diseases" that occur "overwhelmingly or exclusively in developing countries"), agricultural negotiations (focusing on the right to adequate food, market access and human rights), services negotiations requiring the undertaking of human rights impact assessments, and TRIPS negotiations paying particular attention to the impact of trade rules on the human rights of indigenous peoples.

In view of these linkages, the OHCHR has proposed a "conceptual framework for the processes of trade reform that is normatively based on international human rights standards and operationally directed to promoting and protecting human rights". Such a rights-based approach would involve, for example, respecting the principle of non-discrimination, promoting popular participation, monitoring the impact of trade rules and policies on the enjoyment of human rights (especially by vulnerable, marginalised and socially excluded individuals and groups) through the use of human rights impact assessments, and promoting accountability.

However, it is important to note that there are also areas of potential conflict between trade rules and human rights. For example, some of the provisions of the TRIPS Agreement and the Agreement on Agriculture have implications for the human rights of certain groups or individuals (especially the poor) living in the developing and least developed countries (discussed in Part 2 of this article). ${ }^{60}$

57 Emphasis added. Cf. para 5 of the Preamble to the Universal Declaration of Human Rights 1948 in which the Member States of the United Nations have declared their determination to "promote social progress and better standards of life in larger freedom" (emphasis added).

58 See, for example, art XX, which mentions issues such as "public morals", "human health", "prison labour" and "natural resources" (environment).

59 OHCHR Human Rights and Trade, Paper presented to the 5th WTO Ministerial Conference, Cancun, Mexico, 10-14 September 2003 available at http://www.unhchr.ch/html/hchr/cancunfinal.doc (access confirmed: 22 February 2008). See also Cottier "Trade and Human Rights: A Relationship to Discover" (2002) 5 Journal of International Economic Law 111; Lim (fn 2 above).

60 One example is the rules of intellectual property which have rendered it difficult for millions around the world to access essential (and, in many cases, life-saving) medicines. Trade policies concerning the provision of basic services such as water and education can also potentially adversely impact on the enjoyment of human rights. 
There is also a link between development and human rights in that sustainable development aims to achieve the realisation of human rights and, ultimately, the dignity of all human beings. Arguably, all other fundamental human rights are linked to and dependent on the realisation of the right to development. Thus, for example, the ESCR Committee has acknowledged the advantages of a global trading system with objectives that are compatible with sustainable development. ${ }^{61}$

\section{THE WTO AND HUMAN RIGHTS ${ }^{62}$}

Human rights advocates have often expressed concern about the human rights implications of developments within the WTO. Among the rights mentioned in this regard are the right to health, the right to food, the right to education, labour rights, women's rights and indigenous peoples' rights. ${ }^{63}$ The question that arises is whether the WTO as an international organisation is bound by international human rights law. In this section, I examine the place of human rights in the WTO system and attempt to answer the question as to whether the WTO has any human rights obligations. This will set the context for the discussion concerning the human rights implications of the TRIPS Agreement and the Agreement on Agriculture in Part 2 of this article.

\subsection{The primacy of international human rights law}

It has been contended that international human rights law has primacy over all other conventional international law, including that found in trade agreements, and that, in the event of conflict between trade rules and human rights norms, the latter must prevail. ${ }^{64}$ This assertion is based on the principle of the primacy of international human rights law which derives from the UN Charter together with the Universal Declaration of Human Rights (UDHR). ${ }^{65}$ Article 1(3) of the Charter sets human rights as the cornerstone for the achievement of the purposes of the United Nations. Article 55 provides that the UN will encourage "universal respect for, and observance of, human rights and fundamental freedoms for all, without distinction as to race, sex, language or religion", while article 56 imposes an obligation on UN Member States "to take joint and separate action in cooperation with the Organisation for the achievement of the purposes set forth in article 55". It is therefore clear that

61 See UN Doc.E/C.12/1999/9 (34 above) at para 1.

62 In general, see Dommen (fn 2 above); Marceau "WTO dispute settlement and human rights" (2002) 13 European Journal of International Law 753-814; Ala'i "A Human Rights Critique of the WTO: Some Preliminary Observations” (2001) 33 George Washington International Law Review 537; Cleveland "Human rights sanctions and the World Trade Organisation" in Francioni (ed) Environment, human rights and international trade (2001) 199-261; Cohn "The World Trade Organization: elevating property interests above human rights" (2001) 29 Georgia Journal of International \& Comparative Law 427-440; Lim (fn 2 above); Appleton "The World Trade Organization: Implications for human rights and democracy" (2000) 29 Thesaurus Acroasium 415-462; Qureshi "International trade and human rights from the perspective of the WTO" in Weiss, Denters and de Waart (eds) International economic law with a human face (1998) 159-173.

63 See Dommen (fn 2 above) at 13 and Clapham (fn 2 above) at 162-163.

64 See, for example, Howse and Mutua (fn 3 above).

65 Adopted and proclaimed by General Assembly resolution 217A(III) of 10 December 1948. 
UN Member States are obliged to respect human rights. The pre-eminence of this obligation is confirmed by article 103 of the Charter:

"In the event of a conflict between the obligations of the Members of the United Nations under the present Charter and their obligations under any other international agreement, their obligations under the present Charter shall prevail."

The import of this provision is that, while states are bound to fulfil their obligations under the treaties establishing international organisations such as the WTO and others, they must do so in a manner consistent with their obligations as members of the UN, including the obligation to cooperate with the organisation in its quest to promote universal respect for human rights. As Skogly argues, states cannot establish international obligations in order to avoid their obligations under international law. ${ }^{66}$

It is worthy of note that the UDHR proclaims that it is "a common standard of achievement for all peoples and all nations, to the end that every individual and every organ of society... shall strive to secure (the) universal and effective recognition and observance" of the fundamental rights and freedoms enshrined in it. While the legal standing of the UDHR remains a matter of controversy, it may be contended that the constant references to it in numerous international forums and international human rights treaties, as well as in the legislative and judicial proceedings of many countries, indicate that many of its provisions have become part of customary international law binding even on those states that did not approve it in 1948.

A number of resolutions adopted by the key UN human rights bodies also make it clear that international economic policy, including trade, must be consistent with international human rights norms. Thus, in its Resolution on Intellectual Property Rights and Human Rights, the Sub-Commission on the Promotion and Protection of Human Rights reminded all governments of "the primacy of human rights obligations over economic policies and agreements" and requested "all Governments and national, regional and international economic policy forums to take international human rights obligations and principles fully into account in international economic policy formulation". ${ }^{67}$

In its Resolution 2005/17 the UN Commission on Human Rights recognised that "globalisation should be guided by the fundamental principles that underpin the corpus of human rights, such as equality, participation, accountability, non-discrimination, at both the national and international levels" and affirmed the need for multilateral institutions to "recognise,

66 Skogly The Human Rights Obligations of the World Bank and the International Monetary Fund (2001) ch 5 .

67 UN Doc.E/CN.4/Sub.2/2000/7, 17 August 2000. See also Sub-Commission Resolution 1999/30 of 26 August 1999 on trade liberalisation and its impact on human rights, UN Doc.E/CN.4/Sub.2/ RES/1999/30; Resolution 2001/4 of 15 August 2001 on liberalisation of trade in services and human rights, UN Doc.E/CN.4/Sub.2/RES/2001/4; Resolution 2001/21 of 16 August 2001 on intellectual property rights and human rights, UN Doc.E/CN.4/Sub.2/RES/2001/21; and Resolution 2002/11 of 14 August 2002 on human rights, trade and investment, UN Doc.E/CN.4/Sub.2/RES/2001/11. 
respect and protect all human rights”. ${ }^{68}$ The Resolution further affirmed "the commitment to an open, equitable, rule-based, predictable and nondiscriminatory multilateral trading and financial system to ensure that there is greater complementarity between the basic tenets of international trade law and international human rights law".

It is generally accepted that the obligation to respect human rights is erga omnes. ${ }^{69}$ In its General Comment No. 31, the UN Human Rights Committee stated that "the rules concerning the basic rights of the human person" are erga omnes. ${ }^{70}$ To the extent that human rights are obligations erga omnes or have the status of custom, or of general principles, they should take precedence over conflicting rules of international law such as trade agreements. ${ }^{71}$

It is also arguable that the fact that the WTO has international legal personality, which confers upon it certain rights and obligations, means that it is obliged at least to respect human rights. ${ }^{72}$ This question is examined next.

\subsection{Does the WTO have any human rights obligations?}

It should be noted that the various WTO agreements do not explicitly mention human rights or related international instruments: they all focus on the liberalisation of trade through contracting. Further, the WTO itself takes the view that it is a trade organisation and not a human rights organisation. ${ }^{73}$ However, the WTO Agreement which establishes the framework of the entire WTO system sets out a number of objectives which arguably relate to particular human rights obligations - in particular, economic, social and cultural rights. It establishes the objectives of free trade as being related to the achievement of basic human needs, including the improvement of living standards for all people and sustainable development. Paragraph 1 of the Preamble states:

68 Adopted by a vote of 38 to 15 at the Commission"s fiftieth meeting on 14 April 2005, UN Doc.E/ CN.4/2005/L.10/Add.10. See also Commission on Human Rights Resolution 2002/28 of 22 April 2002, UN Doc.E/CN.4/RES/2002/28; Resolution 2003/23 of 22 April 2003, UN Doc.E/CN.4/ RES/2003/23; and Resolution 2004/24 of 16 April 2004, UN Doc.E/CN.4/RES/2004/24.

69 Obligations erga omnes are those obligations binding on all states and in whose observance all states have a legal interest. See Barcelona Traction Case (Belgium v Spain) 1970 ICJ Rep 3. This obligation also implies a duty of solidarity among all states to ensure as rapidly as possible the effective protection of human rights worldwide.

70 Human Rights Committee General Comment No. 31: Nature of the General Legal Obligation Imposed on States Parties to the Covenant, 26 May 2004, CCPR/C/21/Rev.1/Add.13 (General Comment), par 1.

71 See Howse and Mutua (fn 3 above). See also Hestermeyer Human Rights and the WTO: The Case of Patents and Access to Medicines (2007) 101-102. Unlike treaty law, which is based on the express consent of states, customary international law - which arises from a general and consistent practice of states followed by them out of a sense of legal obligation - binds all states.

72 See Lumina "An assessment of the human rights obligations of the World Bank and the International Monetary Fund with particular reference to the World Bank"s Inspection Panel" (2006) 31 (2) Journal of Juridical Science 108, 123. A Counsellor for the Legal Division of the WTO has expressed the view that the WTO agreements should be interpreted in a manner that is cognisant of human rights values. See Marceau (fn 60 above) 755. See also Clapham (fn 2 above) 163 where the author argues that the WTO "has sufficient international personality to be bound by the international customary law of human rights".

73 See WTO (fn 28 above) para 11 et seq. 
"Relations in the field of trade and economic endeavour should be conducted with a view to raising standards of living, ensuring full employment and a large and steadily growing volume of real income and effective demand". ${ }^{74}$

This provision is couched in language that is very similar to that employed in article 55(a) of the UN Charter, which states:

"The United Nations shall promote higher standards of living, full employment, and conditions of economic and social progress and development in the economic and social order".

It appears, therefore, that the drafters of the WTO Agreement intended to make clear reference to the UN Charter. In essence, they recognised the primacy of the principles in the UN Charter.

It is notable that articles 25(1) and 23 of the UDHR provide, respectively, for the right to an adequate standard of living and the right to work. These rights have been elaborated in legally binding form in article 11 of the International Covenant on Economic, Social and Cultural Rights of 1966 (ICESCR) which guarantees the right of everyone to an adequate standard of living and in articles 6 to 8 of the same instrument which provide for the right to work.

Other WTO agreements, such as the Agreement on Government Procurement (GPA), the General Agreement on Trade in Services (GATS) and GATT, contain provisions with human rights implications. For example, article XXIII of the GPA makes reference to measures relating to the products or services of handicapped persons (relevant to the prohibition on discrimination which is enshrined in numerous human rights instruments) and products of prison labour (relevant to the prohibition on forced or compulsory labour). Article XIV (c)(ii) of the GATS refers to the protection of the privacy of individuals in relation to the management of data (relevant to the right to privacy).

Although the text of the GATT also does not explicitly mention human rights, it contains provisions with sufficient scope for states to protect and promote human rights through trade by taking certain measures against states that violate human rights. Thus, article XX provides for exceptions that would not constitute arbitrary discrimination or a disguised restriction on international trade. These include measures to protect public morals; ${ }^{75}$ human, animal or plant life or health; ${ }^{76}$ and measures concerning goods produced through prison labour. ${ }^{77}$ It has been contended, however, that the potential usefulness of the non-trade public values in article XX has been considerably weakened by a "very restrictive interpretation". ${ }^{78}$

Further, as Howse and Mutua have argued, the objectives of trade liberalisation as set out in the WTO Agreement can only be achieved in the context

\footnotetext{
74 Sub-regional trade agreements in Africa such as the COMESA, ECOWAS and SADC treaties all have as one of their objectives the raising of the living standards of the people within their region. See COMESA Treaty, art 3(b); Treaty of ECOWAS, art 3(1); and Treaty of the Southern African Development Community (as amended), art 5(1)(a).

75 Art XX (a).

76 Art XX (b).

77 Art XX (e).

78 Howse and Mutua (fn 3 above).
} 
of respect for human rights. ${ }^{79}$ They state that the growing number of sectors covered by multilateral trade and investment agreements in an era of rapid economic globalisation has enlarged the potential for new human rights abuses that are not adequately covered under existing international human rights standards. Examples of these include the response of the Nigerian military government under Abacha to the Ogoni people's quest to protect their fundamental rights in relation to the environmental damage caused by foreign-owned oil companies in the Niger Delta and numerous violations of workers' rights in several Asian countries through sweatshops, child labour and bonded labour.

In similar vein, as noted already, the ESCR Committee has expressed the view that trade liberalisation "must be understood as a means, not an end" and that the end which it should serve is "the objective of human well-being to which the international human rights instruments give legal expression". 80

It is therefore arguable that human rights, as universal values and obligations erga omnes, should prevail over any international rules aimed at facilitating trade that are inconsistent with them. In the event of conflict between a universally recognised human right and a commitment under international trade agreement, the latter must be interpreted so as to be consistent with the former. In this regard, since the WTO Agreement and its Annexes do not explicitly contract out of general standards of human rights law, it has been asserted that the WTO is bound by the general international standards of human rights ${ }^{81}$ and, in the event of a contradiction between WTO law and international human rights standards, the WTO is bound by the latter where these have attained the status of jus cogens. ${ }^{82}$ Article 53 of the Vienna Convention on the Law of Treaties clearly states that treaties in conflict with peremptory norms (i.e. norms that have the character of jus cogens) are void:

"A treaty is void if, at the time of its conclusion, it conflicts with a peremptory norm of general international law. For the purposes of the present Convention, a peremptory norm of general international law is a norm accepted and recognised by the international community of States as a whole as a norm from which no derogation is permitted and which can be modified only by a subsequent norm of general international law having the same character".

International judicial decisions also reaffirm the peremptory (or absolute) character of some human rights, such as the right to life and the prohibitions of torture, slavery, genocide and racial discrimination. ${ }^{83}$

79 Ibid.

80 See fn 36 above.

81 Hestermeyer (fn 71 above) 101.

82 Ibid 101-102. See also Orakhelashvili Peremptory Norms in International Law (2006) 8

83 See, for example, Prosecutor v Furundzija, Case No IT-95-17/I-T, pars 147-155, Judgment of 10 December 1998 (ICTY); Prosecutor $v$ Kunarac, Case No IT-96-23-T, par 454, Judgment of 22 February 2001 (ICTY); Juridical Condition \& Rights of the Undocumented Migrants, Advisory Opinion OC-18/03 of 17 September 2003, para 101 (IACHR). 
Since the WTO rules and institutions operate within the broader framework of international law, ${ }^{84}$ the interpretation of the WTO agreements must be consistent with the rules of interpretation set forth in article 31 of the Vienna Convention. ${ }^{85}$ The Appellate Body of the WTO has stressed that article 31 of the Vienna Convention is an important reference point for WTO dispute settlement. Paragraph 3(c) of article 31 of the Convention, which adverts to "any relevant rules of international law applicable in the relations between the parties", allows for the application of non-WTO law (including human rights law) in the resolution of disputes by the WTO dispute settlement mechanism. ${ }^{86}$ Thus, for example, in US-Shrimp, the Appellate Body was called upon to determine the meaning of the expression "exhaustible natural resources" under GATT article XX(g). ${ }^{87}$ In order to determine the scope of the provision, the Appellate Body referred to international environmental law as it had developed since the adoption of the original GATT. It went on to state:

"The words of Article XX (g), "exhaustible natural resources", were actually crafted more than 50 years ago. They must be read by a treaty interpreter in the light of contemporary concerns of the community of nations about the protection and conservation of the environment. While Article XX was not modified in the Uruguay Round, the preamble attached to the WTO Agreement shows that the signatories to the Agreement were, in 1994, fully aware of the importance and legitimacy of environmental protection as a goal of national and international policy. The preamble to the WTO Agreement - which informs not only the GATT 1994, but also the other covered agreements - explicitly acknowledges "the objective of sustainable development". ${ }^{88}$

In the Appellate Body's view, the terms of treaties are not static but must be interpreted in the light of the contemporary meaning and, from "the perspective embodied in the preamble to the WTO Agreement", it was apparent "that the generic term- natural resources" in Article XX (g) is not "static" in its content or reference but is rather "by definition, evolutionary". ${ }^{99}$ Consequently, WTO Members could take measures which were otherwise in breach of their obligations under GATT to protect endangered species in terms of the exception provided for by article XX(g). The Appellate Body held that the term "exhaustible natural resources" included endangered species such as the sea

84 In US-Gasoline, the Appellate Body stated that the WTO Agreement could not be read in "clinical isolation from public international law" (United States-Standards for Reformulated and Conventional Gasoline, WT/DS2/AB/R (1996) 17). See also Article 3(2) of the Understanding on Rules and Procedures Governing the Settlement of Disputes ("the Dispute Settlement Understanding" or "DSU") which requires the WTO agreements to be interpreted in accordance with customary rules of interpretation of public international law.

85 Article 31(1) of the Vienna Convention provides that a treaty must be interpreted "in good faith in accordance with the ordinary meaning to be given to the terms of the treaty in their context and in the light of their of its object and purpose". The rules are considered to be rules of customary international law and therefore binding even on the non-State Parties to the Convention. See USGasoline (82 above) 17; Territorial Dispute (Libyan Arab Jamahiriya $v$ Chad) ICI Reports 1994, 4, para 41; Gabcikovo-Nagymaros Project (Hungary v Slovenia), ICJ Reports 1997, 7, para $42-46$ and 99. See also Aust Modern Treaty Law and Practice (2000) 10-11, $184 \mathrm{ff}$.

86 See, for instance, European Communities - Measures Affecting the Approval and Marketing of Biotech Products, WT/DS291/R, par 7.67 (2006).

87 United States - Import Prohibition of Certain Shrimp and Shrimp Products, WT/DS58/AB/R, pars 127-132 (1998).

88 Ibid para 129-130.

89 Ibid para 129-132. 
turtle. ${ }^{90}$ According to the Appellate Body, such an "evolutionary approach" was, in general, the appropriate method for interpreting the meaning of treaty terms. ${ }^{91}$

Similarly, in EC-Bananas, the Appellate Body referred to the Lomé Convention to interpret a waiver. ${ }^{92}$ The Appellate Body noted that, to the extent that the GATT Contracting Parties had incorporated a reference to the Lomé Convention in the Lomé waiver, the meaning of the Lomé Convention became a GATT/WTO issue, which left the Appellate Body no alternative but to examine the provisions of the Lomé Convention in so far as it was necessary to interpret the Lomé waiver. ${ }^{93}$

It is thus clear from the jurisprudence of the WTO dispute settlement mechanism that non-WTO international standards can be used as aids in the interpretation of the covered agreements. However, it is important to emphasise that article 31(1)(c) of the Vienna Convention will only apply where the rule of international law in question is relevant or applicable to the facts of the case at hand and where the rule is "applicable in the relations between the parties" - that is, binding on the parties. ${ }^{94}$

It has been argued that the terms "public morals", "human life or health" and "prison labour" in article XX of the GATT should also be interpreted using an "evolutionary approach", given that these concepts have evolved since the commencement of universal human rights standard-setting by the UN..$^{95}$ This, it is asserted, would "recognise modern respect for international human rights norms and standards". ${ }^{96}$ Thus the WTO dispute settlement mechanism can, through innovative and flexible interpretation of the provisions of the WTO agreements, arguably contribute to the promotion and protection of human rights. As Gabrielle Marceau, Counsellor for Legal Affairs at the WTO, has suggested: "a good faith interpretation of the relevant WTO and human rights provisions should lead to a reading of WTO law coherent with human rights". ${ }^{97}$

90 Ibid.

91 Ibid para 134. This approach to treaty interpretation takes changes in society into consideration. See Bernhardt "Evolutive Treaty Interpretation, especially of the European Convention on Human Rights" (1999) 42 German Yearbook of International Law 11, 12; Letsas "The Truth in Autonomous Concepts: How to Interpret the ECHR" (2004) 15 European Journal of International Law 279, 301302. See also Legal Consequences of the Continued Presence of South Africa in Namibia (South West Africa) notwithstanding Security Council Resolution 276 (Advisory Opinion), 1971 ICJ Reports 31, where the International Court of Justice stated that where the concepts embodied in a treaty are "by definition, evolutionary", their "interpretation cannot remain unaffected by the subsequent development of law... Moreover, an international instrument has to be interpreted and applied within the framework of the entire legal system prevailing at the time of the interpretation".

92 European Communities - Regime for the Importation, Sale and Distribution of Bananas, WT/DS27/ $\mathrm{AB} / \mathrm{R}$, para 167 (1997).

93 Ibid.

94 Hestermeyer (fn 71 above) 221.

95 OHCHR Human Rights and World Trade Agreements: Using General Exception Clauses to Protect Human Rights (2005) 7-8. See also Marceau (fn 62 above) 784.

96 OHCHR (fn 95 above).

97 Marceau (fn 62 above) 755. 


\section{CONCLUSION}

Despite the aforementioned, it is important to emphasise that the mandate of the WTO dispute settlement mechanism is limited to the interpretation of WTO agreements and determination of whether there has been a violation of a provision of the covered agreements. ${ }^{98}$ Thus, it cannot enforce or give direct effect to human rights provisions other than in the context of the provisions of the WTO agreements. ${ }^{99}$

\section{(To be continued)}

\section{BIBLIOGRAPHY}

Ala'i P "A human rights critique of the WTO: some preliminary observations" (2001) 33 George Washington Journal of 537

Allmand W "Trading in Human Rights: The Need for Human Rights Sensitivity at the World Trade Organisation” A Brief by W Allmand (President ICHRDD) to the Standing Committee on Foreign Affairs and International Trade. Montreal (24 March 1999) Rights and Democracy available at http:// www.ichrdd.ca/english/commdoc/publications/globalization/globalAllmand.html (access confirmed: 30 January 2007)

Appleton AE "The World Trade Organization: implications for human rights and democracy" (2000) 29 Thesaurus Acroasium 415-462

Aust A Modern Treaty Law and Practice (2000)

Benedek W "The World Trade Organization and Human Rights" in Benedek W De Feyter K and Marrella F (eds) Economic Globalization and Human Rights (2007) 137

Bernhardt R "Evolutive Treaty Interpretation, Especially of the European Convention on Human Rights” (1999) 42 German Yearbook of International Law 11

Bhagwati J In Defense of Globalization (2004)

Cardoso FH and Faletto E Dependency and Development in Latin America Translated by Marjory M Urquidi (1979)

Clapham A Human Rights Obligations of Non-State Actors (2006)

\footnotetext{
98 See Articles 1, 4, 7 and 11 of the Understanding on Rules and Procedures Governing the Settlement of Disputes (DSU).

99 Marceau (fn 62 above) 763.
} 
Cleveland SH "Human rights sanctions and the World Trade Organization" in Francioni F (ed) Environment, human rights and international trade (2001) 199

Cohn M "The World Trade Organization: elevating property interests above human rights" (2001) 29 Georgia Journal of International \& Comparative Law 427

Cottier T "Trade and Human Rights: A Relationship to Discover” (2002) 5 Journal of International Economic Law 111

Cottier T Pauwelyn J and Burgi Bonanomi (eds) Human Rights and International Trade (2005)

De Wet E "Labour Standards in the Globalized Economy: the inclusion of a Social Clause in the General Agreement on Tariffs and Trade/ World Trade Organization" (2002) 36 Journal of World Trade 883

Dommen C "Raising Human Rights Concerns in the World Trade Organization: Actors, Processes and Possible Strategies" (2002) 24 Human Rights Quarterly 1

Eisenberg J Free Trade versus Fair Trade available at http:/www.aworldconnected.org/article.php?id=5608print $=1$ (access confirmed: 12 July 2006)

Friedman M Capitalism and Freedom 2 ed (1982)

Friedman M and Friedman RD "The Case for Free Trade" (1997) 4 Hoover Digest available at http://www.hoover.org/publications/digest/3550727.html (access confirmed: 30 January 2007)

Global Exchange The WTO Erodes Human Rights Protections - Three Case Studies (1999) available at http://www.globalexchange.org/wto/CaseStudies.html (access confirmed: 17 September 2007)

Hestermeyer H Human Rights and the WTO: The Case of Patents and Access to Medicines (2007)

Howse R "How to Begin to Think About the 'Democratic Deficit' at the WTO" in Griller S (ed) International Economic Governance and Non-Economic Concerns (2003) 79

Howse R and Mutua M Protecting Human Rights in a Global Economy: Challenges for the World Trade Organization available at http://www.dd-rd.ca/ english/commdoc/publications/globalization/wtoRightsGlob.html (access confirmed: 21 August 2006)

Irwin DA Against the Tide: An Intellectual History of Free Trade (1996)

Irwin DA Free Trade under Fire (2002)

Jackson JH The World Trade Organization: Constitution and Jurisprudence (1998)

Kanji N and Barrientos S Trade Liberalisation, poverty and livelihoods: understanding the linkages (2002)

Kothari M "Globalisation, Social Action and Human Rights" in Mehra M (ed) Human Rights and Economic Globalisation: Directions for the WTO (1999) 
Letsas G "The Truth in Autonomous Concepts: How to Interpret the ECHR" (2004) 15 European Journal of International Law 279

Lim H “Trade and Human Rights - What's at Issue?” (2001) 35(2) Journal of World Trade 275

Lindsey B Against the Dead Hand: The Uncertain Struggle for Global Capitalism (2001)

Lumina C "An assessment of the human rights obligations of the World Bank and the International Monetary Fund with particular reference to the World Bank Inspection Panel” (2006) 31(2) Journal of Juridical Science 108

Marceau G "WTO Dispute Settlement and Human Rights" (2002) 13(4) European Journal of International Law 753

McCulloch N Winters LA and Cirera X Trade Liberalization and Poverty: A Handbook (2002)

OHCHR Human Rights and Trade Agreements: Using General Exception Clauses to Protect Human Rights (2005)

OHCHR Human Rights and Trade, Paper presented to the 5th WTO Ministerial Conference, Cancun, Mexico, 10-14 September 2003 available at http:// www.unhchr.ch/html/hchr/cancunfinal.doc (access confirmed: 22 February 2008)

Orakhelashvili A Peremptory Norms in International Law (2006)

Oxfam Cut the Cost, Patent Injustice: How World Trade Rules Threaten the Health of Poor People (2001)

Oxfam Patents versus Patients: Five Years after the Doha Declaration Oxfam Briefing Paper (2006)

Oxfam Rigged Rules and Double Standards: Trade, Globalization, and the Fight Against Poverty (2002)

Pauwelyn J Conflict of Norms in Public International Law: How WTO Law Relates to other Rules of International Law (2003)

Pollard S Mingardi A Philippe C and Gabb S EU Trade Barriers Kill. A Centre for the New Europe Report (September 2003) available at http://www.cne. org/pub_pdf/2003_09_04_EU_barriers_kill_pdf (access confirmed: 30 January 2007)

Qureshi AH "International trade and human rights from the perspective of the WTO” in Weiss F Denters E and de Waart P (eds) International economic law with a human face (1998) 159

Ricardo D Principles of Political Economy and Taxation (1971)

Singleton A Trade Justice or Free Trade? (2005) available at http://www.globalisationinstitute.org/publications/tradejustice.pdf (access confirmed: 30 January 2007)

Skogly S Beyond National Borders: States' Obligations in International Cooperation (2006)

Skogly S The Human Rights Obligations of the World Bank and the International Monetary Fund (2001) 


\section{LAW, DEMOCRACY \& DEVELOPMENT}

Smith A The Wealth of Nations (1776)

Srinivasan TN "Trade and Human Rights" in Deardoff AV and Stern RM Constituent Interests and US Trade Policies (1998) 225

Thomas IS and Meyer MA The New Rules of Global Trade: A Guide to the World Trade Organization (1997)

UNDP Integrating Human Rights with Sustainable Human Development (1998)

Vander Weyer M “Can Free Trade Be Fair?” New Statesman available at http:// www.newstatesman.com/200502280013 (access confirmed: 28 February 2008)

Wolf M Why Globalization Works (2004)

World Bank Attacking Poverty: World Development Report 2000/2001 (2001)

Wouters J and De Meester B The World Trade Organization: A Legal and Institutional Analysis (2007)

WTO Understanding the WTO (2003, rev. 2007) 